puint, so that, when the zine particles next to the metal have been destroyed by anodic attack, contact will be maintained with those in the outcr part of the conting; barium and/or calcium phosphates may also be added to convert the more aecessible part of the ferrous sulphato to harmless compounds (phosphates of iron and sulphates of barium and calcium). Paints thus compounded, appliod over rust containing forrous sulphate and other salts, have shown encouraging results in tests at Cambridge ${ }^{20}$. An account of service tests in a humid, saline and highly corrosive atmosphere overseas will shortly be published.

It would be wrong to assume that this sanctions the practice of painting over any rusted surface; the paints will only prevent disaster if contact between zinc and stecl can be established. Where this is possible, the principle is sound. The success of a zinc-contact method in arresting 'bronze disease' shows that the method is effective when contact can be maintained ${ }^{21}$. During the Second World War, a largo number of beautiful and valuable bronze antiques were evacuated from the Fitzwilliam Museum, Cambridge, to a place of safety. After the war, they were returned to the Museum, but soon developed a form of intense local corrosion which, on articles which had romained undamaged for more than 2,000 years, started to produce perforation within a matter of weeks; the inward-moving ions were probably $\mathrm{CH}_{3}-\mathrm{COO}-$, derived from the wooden shavings in which the antiques had been packed. It is known that washing with water fails to arrest this virulent 'disease'-doubtless for the reasons explained here. A method was worked out in which a zine anode (cut into the form of $a \mathrm{nib}$ ) and wettcd in turn with: (1) hydrochloric acid; (2) phosphoric acid; (3) sodium carbonate solutions was used to seratch the points of attack. The aggressive ions were quickly fetched out and the corrosion ceased. The treatment could be applied locally, the main surface remaining unwetted, so that the beautiful green patina was not disturbed. About 500 antiques were thus treated in $1950-51$ by Mr. N. Rayner (now senior assistant, Department of Antiques); only one failed to respond to the treatment, and an inspection 14 yoars later shows that the cure has been permanent22. Rayner writes that it is "by far the most effective treatment I know and also the simplest".

${ }^{2}$ Evans, U. R., and Hoar, T. P., Proc. Roy. Soc., A. 137, 343 (1932).

2 Thornhill, R. S., and Evans, U. R., J. Chem. Soc., 614 (1938).

${ }^{3}$ Brown, 1. H., and Mears, R. B., Trans. Electrochem. Soc., 74, 495 (1938); 81, 455 (1942).

- Agar, J. N. : see Evans, U. R., J. Iron and Steel Inst., 141, 221P (1940).

- Rosenfeld, I. L, First Intern. Congress Met. Corr. 1961, 243 (Butterworths 1962). See also Mayne, J. E. O., Vernon, W. H. J., 251.

- Vernon, W. H. J., J. Inst. Metals, 48, 121 (1932).

${ }^{7}$ Preston, R. St. J., and Tholen, J., Chemistry Research, 18 (E.M. Stationery once, 1948).

${ }^{8}$ Vernon, W. H. J., Chem. und Indust., 62, 318 (1943); J. Roy. Soc. Arts, 97, 589 (1949).

- Schikorr, G., Werkstoffe und Korrosion, 14, 69 (1963); 15, 457 (1964). Dr. Schjkorr writes (1965) that his equations represent the overall reac tion and do not cxclude an electrochemical mechanism.

${ }^{20}$ Evans, U. R., Trans. Faraday Soc., 19, 201 (1923).

${ }^{11}$ Evans, U. R., Trans. Inst. Met. Finishing, 37, 1 osp. 5 (1960).

1" Tanner, A. R., Chem. and Yndust., 1027 (1964). Thornhill, R. S., detected $\mathrm{FeSO} \mathrm{O}_{4} 4 \mathrm{H}_{2} \mathrm{O}$ below outdoor rust in 1952 , but the observation was not published. Recently the distribution of ferrous gulphate below outdoor rosion, 16, 93, $208(1965)$.

13 Hoar, T. P. (personal communication).

is Hoar, T. P., Trans. Faraday Soc., 33, 1152 (1937).

${ }^{15}$ Edeleanu, C., and Evans, U. R., Trans. Faraday Soc., 47, 1121 (1951).

${ }^{10}$ Vernon, W. H. J., Conservation of Natural Resources (Inst. Civ. Engrs, 105. ernon, W. H. J., Co
esp. 130, 1956-57).

${ }^{17}$ Hudson, J. C., Code of Practice on the Protection of Iron and Steel Structures from Corrosion (British Stavdards Institution, in the pross).

${ }^{18}$ Mayne, J. E. O., J. App. Chem., 9, 673 (1959).

${ }^{10}$ Evans, U. R., J. Soc. Chem. Indust., 47, 55T (1028).

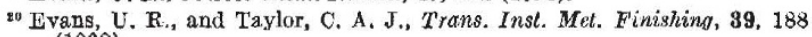
(1062).

${ }^{21}$ Evans, U. R., Chem. and Indust., 710 (1951).

${ }^{22}$ Rayner, N. (personal communication).

\title{
THE PLACE OF UNIVERSITIES IN MODERN SOCIETY
}

$\mathrm{L}^{\mathrm{O}}$ ORD BOWDIEN, Minister of State for Science, gave 4 an address to the Australian Institute of Political Scienco in Canberra on January 30, 1965. His paper was published in full in Comparative Education (1, No. 2, March 1965; Pergamon Press, Oxford); the following articlo consists of extracts from it illustrating the main points.

"Many people have discussed the size and the expansion of the cost of universities at great length. I would like to-day to come to grips with a moro elusivo and complex issue, and to talk about the function of universitios. What do we expect thom to do for society? It is useful to remember that Amorican universities have twenty times as many students as ours in England, and to stross the fiset that, whereas one young person in twenty-five goos to university in England and one in eight goes in Australia, nearly half the population goes to college in California.

"Three years ago the House of Cummons debated the universities. Throughout the whole dobate evory speaker concontrated on undergraduato education. The teaching of undergraduates is, of course, essential and vital, but I believe that it is only one of three equally important and quite separate functions of a modorn university. For, mako no mistake, no modorn state can thrive and adapt itsolf to this changing world unless it is supportcd and encouraged by its universities, and unless the universities themsolvos have a proper undorstanding of the unique obligations they owe to the State which supports them, and which gives them so many and such important privileges.

"If we are to see theso problems in perspectivo we shall have to talk of the history of universities in England, and the poculiar traditions we have inhorited. Tho Industrial Revolution was ignored by the English universities; it was made by self-taught men. Our English industrial revolution may have come about by chance, but other countries which envied our wealth deliberately decided to develop their own industries. They realized that modern industry demands engineers and scientists in large numbers, and they conceived of the extraordinary idea that if such men aro needed they must be educated. Special technical universities were founded all over Europe throughout the past century, and the first such university in Australia was established in New South Wales a fow years ago. I believe that the new universities, which were established, lot us remind ourselves, to help Europe and America to compete with industrial Lancashire, had within thom the seeds of the second industrial revolution which is transforming the world beforo our eyes. English universities never soem to have appreciated. the part that the universities of othor countries have played in the evolution of our modern world, nor have they done all that they should have done to further the industrial growth of their native land. I think that they will have to change their wholo outlook on themselves and on society if Great Britain is ever to rocover hor position as a great manufacturing country."

Lord Bowden went on to describe the establishment of the "Land Grant" colleges in Ameriea, from which most American State universities have devoloped, including the Massachusotts Institule of Technology (M.I.T.). He entinued: "For the first time universities were to combine vocational and liberal studies and provide opportunities for the educationally underprivileged. They studied the problems which beset society, whatever 
they might be ; they tried to bring modern diseoveries to the attention of all eitizens capable of understanding them and using them ; and, of course, they taught undergraduates. Research, adult education and undergraduate teaching were to be equally important. They are to this day. But we must never forget that many of the best American and English engineers have been educated in the great technical universities of Europe. Furthermore, America imported the new European academic traditions along with her scientists and engineers. They had studied practical problems for years, but it was Germany which showed America that pure research could be useful and important to American universities. University research has grown so much since the war that it dominates the entire university system and has changed the very nature of universities. In 1938, the M.I.T. spent about $\$ 140,000$ on research. Last year they spent about $\$ 140$ milliona thousand times as much, and about as much as all our English universities put together.

"Any well-established American university, or any well-known research worker, can persuade some government department or other to invite him to accept a contract to do something that he has already decided that he wants to do anyway. But whenever the Federal Govern. ment decides that some burning problem must be studied forthwith their advisers always know of some university, somewhere, which would like to oblige, and build up its graduate school and perhaps become famous in the process. You may say that the Government has taken over the American universities. In a sense this is true; at the same time the universities have taken over the central government and the whole nature and structure of American government has been transformed. They have in the process produced a new type of society, a new machinery of government unlike anything $I$ have seen anywhere else. The universities themselves are an essential component of this new machine. The system depends on free and frequent interchange of staff between the Government, business and academic world.

"Russian universities all understand very clearly that they are an essential component of society and that they exist to serve it. Their organization is quite unlike anything in America, but it ensures that research and teaching are intimately associated at all stages. Russian universities, research stations and industrial plants are in fact separate and distinct, but it is very hard for a visitor to be sure where one ends and the other begins ; they are all part of a single vast educational and productive machine. But since it would be quite impossible to describe so complex a country as Russia, even if I understood it, I must concentrate on the one principle which seems to me to underlie everything they do. To-day the Russians more than any other people seem to be obsessed by the importance of associating theory with practice, and they have shown extraordinary ingenuity in developing an educational machine to do what they want. About ten years ago at a time of rapid university expansion the Russians began to fear that some of their university students might become a race apart, unaware of their obligations to society, or of the relevance of their studies in preparation for life. The government decided that young people ought to take a job for two years after leaving school before they could be admitted to a university. The Russians find that their students understand the practical importance of their theory and appreciate the great good fortune which has sent them to a university.

"I would like now to speak about adult education. At this moment in time the total amount of scientific knowledge in the world is doubling every fifteen years, three-quarters of all the scientists who ever lived are alive and practising to-day and half of what a man learns as an undergraduate is more or less useless after 10 years or so. It is essential that every professional man should realize that he will have to be educated and re-educated throughout his whole working life. The growth of education and re-education for adults in America has been explosively rapid. There are courses, both professional and non-professional, in everytbing from engineering to painting, both liberal studies and vocational training. The Russians have developed similar programmes on an enormous scale. Almost half of all Russian students do some of their work by correspondence. All universities run suitable courses. Almost anyone in America or in Russia or in Sweden can learn almost any subject which interests him, either in a university, in a small class specially arranged for him by the local university, or by correspondence. England and Australia must not lag behind their industrial competitors.

"It is essential that the universities should help to decide how their own recruits are educated. In other words, the universities must study the schools. If they do not there will be gaps between the world of teaching and the world of practical affairs. I think that all academic institutions, be they schools or universities, have a tendency to isolate themselves from the world, and to ignore the practical implications of the work they do. Up to a point, of course, this process is inevitable, and it is in a sense the very secret of their academic achievement. But in excess it can be dangerous, and even fatal. How, therefore, are Australian and English universities to ensure that what they teach is real, is exciting, changing and contemporary? Surely it must be by associating the university world as closely as possible with the worlds of industry, of commerce and of manufacture. In other words, the interest of the university work for the students, and the value of all academic disciplines, are at stake in this one principle which I have adumbrated, namely that the universities must study the problems of society, or they may lose the intellectual distinction upon which rests their claim to the support which society has given them."

\section{OBITUARY}

\section{Dr. W. J. Hall, C.M.G., M.C.}

WILFRID JoHN HALL, formerly director of the Commonwealth Institute of Entomology, died suddenly at Kaduna, Nigeria, where he was visiting his son, on January 13, 1965 , at the age of seventy-two.

Hall was educated at St. Paul's School and the Imperial College of Science and Technology. He gained his A.R.C.S. in 1914, and almost immediately joined the army, in which he served until 1919, being decorated with the Military Cross and attaining the rank of major. In 1919 he joined the Ministry of Agriculture, Egypt, as entomologist. There he became involved in the study of the systematics, biology and control of scale insects, interests that were to remain throughout his career. In 1927 he was appointed by the British South Africa Company to deal with the insect problems of their extensive citrus estates in Rhodesia. His demonstration of the economic value of basing plantation management on the results of proper scientific investigation led to the establishment, in 1930, of the Mazoe Citrus Experiment Station, with a small but well-balanced research staff under his direction, and in 1933 he also assumed the responsibility of supcrintendent of the Company's estates.

He returned to England in 1943 to join the Common. wealth Institute of Entomology, of which he became assistant director in 1944 and director in 1946. To this post he brought an unusual and apposite combination of scientific talents and experience, a first-hand appreciation 